\title{
Effects of soil hypoxia and salinity on gas exchange and growth of Spartina patens
}

\author{
S. R. Pezeshki, R. D. DeLaune \\ Wetland Biogeochemistry Institute, Center for Coastal, Energy and Environmental Resources, Louisiana State University, \\ Baton Rouge, Louisiana 70803-7511, USA
}

\begin{abstract}
Laboratory experiments were conducted to evaluate the effects of increased soil salinity on gas exchange functioning and growth of the brackish-marsh grass Spartina patens (Ait) Muhl. under controlled soil redox potentials ( $\mathrm{Eh})$ which were maintained at either aerobic $(+489 \mathrm{mV})$ or hypoxic $(-40 \mathrm{mV})$ conditions. Plants were subjected to salinities of $0,5,15$ and 25 ppt gradually over a $7 \mathrm{~d}$ period and leaf tissue chlorophyll content, gas exchange and growth responses were measured. Leaf tissue chlorophyll content was not affected by the treatments. Gas exchange of S. patens was adversely influenced by increases in salinity. Leaf conductance was reduced by $36 \%$ and net photosynthesis by $23 \%$ of control plants under aeration plus 25 ppt salinity, and water use efficiency increased to $161 \%$ of control plants. When increased salinity accompanied hypoxia, leaf conductance and net photosynthesis were reduced by 60 and $44 \%$ of control plants, respectively. The interaction between salinity and hypoxia was not significant. Salinity of $25 \mathrm{ppt} \mathrm{reduced} \mathrm{root} \mathrm{dry} \mathrm{weight,} \mathrm{leaf} \mathrm{dry} \mathrm{weight} \mathrm{and} \mathrm{height}$ growth significantly. Salinity and hypoxia combined affected various biomass components while hypoxia primarily affected root dry weights. Elevated salinity and hypoxia also adversely affected gas exchange functions and growth. Results presented suggested that saltwater intrusion is a major factor contributing to the rapid rate of marsh deterioration in coastal Louisiana (USA) brackish marshes which are dominated by $S$. patens.
\end{abstract}

\section{INTRODUCTION}

In coastal Louisiana, USA, saltwater intrusion occurs in brackish and freshwater marshes as a result of rapid subsidence, a major problem in Louisiana's Mississippi River deltaic plain. Studies have shown that brackish marshes dominated by Spartina patens (Ait) Muhl. are among the predominant vegetation types which are deteriorating faster than any of the other wetland habitats, apparently in response to increased flooding and salinity (Gagliano \& Van Beek 1970, Adams et al. 1976). The combined effects of these factors on coastal vegetation, however, have not been studied in detail (van der Moezel et al. 1989).

Spartina patens is a dominant brackish marsh species found in a wide range of flooding and salinity conditions (Parrondo et al. 1978, Gosselink 1984). However, laboratory and field data indicate that its growth is adversely affected by flooding (Pezeshki et al. 1991) and salinity (Parrondo et al. 1978, Gosselink 1984). The response has been partially attributed to the adverse effects of flood- ing and/or salinity on gas exchange of this species. For example, flooding adversely affected net photosynthesis in S. patens (Pezeshki et al. 1987) and inhibited root elongation in this species (Pezeshki et al. 1991). When soil salinity was increased from 0 to $22 \mathrm{ppt}$ in 2 applications over $8 \mathrm{~d}$, stomatal conductance and net photosynthesis were reduced by 54 and $43 \%$, respectively (Pezeshki et al. 1987).

Previous studies have been directed at the response to salinity of either growth and biomass of U.S. Gulf Coast populations (Parrondo et al. 1978, Gosselink 1984, Pezeshki \& DeLaune 1991) or photosynthesis (Pezeshki et al. 1987, Pezeshki 1991). However, these studies did not control or quantify the redox conditions of the medium in which plants were grown. Although much of the immediate plant responses to reduced soil redox potential (Eh) are primarily due to the absence of oxygen within the root tissue (Gleason \& Zieman 1981, Yamasaki 1987), soil Eh may be used as an indicator of the presence of oxygen in the soil, which in turn influences internal root oxygen content due to changes in 
the gradient of oxygen concentration between aerial parts and the rhizosphere (Yamasaki 1987). Generally, low soil Eh results in low Eh of root cells (Yamasaki 1952).

Previous studies on this species have dealt with hypoxia and salinity separately (Parrondo et al. 1978, Pezeshki et al. 1989, 1991) so little is known about the potential interaction between these 2 factors in Spartina patens. In the U.S. Gulf Coast brackish marshes, hypoxic conditions are usually accompanied by salt stress. The overall objective of this study was to examine the effects of hypoxia and salinity on gas exchange and biomass partitioning in $S$. patens. The specific objectives were to examine: (1) gas exchange responses of $S$. patens to a series of well-defined controlled rhizosphere redox potential (Eh) and salinity conditions; (2) the potential interaction between the effects of salinity and hypoxia on gas exchange functions of this species; and (3) the subsequent effects on biomass partitioning.

\section{MATERIALS AND METHODS}

Plant material. Spartina patens plants were obtained from a brackish marsh stand located in Barataria Basin, Louisiana, USA. The plants were initially grown in commercial potting mixture (Jiffy Mix Plus, Jiffy Products of America, Chicago, IL, USA) in a greenhouse and fertilized with $1 / 10$ strength Hoagland solution (Johnson et al. 1957). The fertilization was on a biweekly schedule in which $50 \mathrm{ml}$ of solution were added to each 41 pot. Plantlets regenerated from these plants were used for different experiments.

Experimental procedures. Sediment was collected from a freshwater marsh area in Barataria Basin. In the laboratory, $225 \mathrm{~g}$ of dry sediment and $1600 \mathrm{ml}$ of $1 / 10$ strength Hoagland solution were mixed in $2 \mathrm{l}$ desiccator bases and were continuously stirred with a magnetic stirrer. Plantlets 7 to $10 \mathrm{~cm}$ in height and uniform in size and appearance were placed through holes in Plexiglas plates designed to fit on top of the desiccator base ( 8 plants per desiccator) containing the soil suspension, and were grown under controlled root rhizosphere Eh conditions (see below) inside a growth chamber. The growth chamber was maintained at light periods of $14 \mathrm{~h}\left(25^{\circ} \mathrm{C}, 70 \%\right.$ relative humidity) and dark periods of $10 \mathrm{~h}\left(20^{\circ} \mathrm{C}, 85 \%\right.$ relative humidity). Photosynthetic photon flux (PPF) provided by a combination of fluorescent and incandescent lamps was 700 to $900 \mu \mathrm{mol} \mathrm{m} \mathrm{m}^{-2} \mathrm{~s}^{-1}$ at the top of the plants. The PPF was reduced to $200 \mu \mathrm{mol} \mathrm{m} \mathrm{m}^{-2} \mathrm{~s}^{-1}$ during the first and last hour of each photoperiod.

The system for controlling the Eh in the sediment in which the plants were grown is described in detail by
Reddy et al. (1976) and Pezeshki et al. (1989). This consisted of a desiccator Plexiglas plate (containing plants as described earlier) to which a miniature motor was attached to drive an impeller to keep the soil in suspension. Impeller and shaft were shielded with a $10 \mathrm{~mm}$ diameter Plexiglas tube attached to the upper plate to prevent root damage. Each unit also contained a meter relay, platinum electrodes, a calomel half-cell connected to the soil suspension with a saturated $\mathrm{KCl}$ agar salt bridge and other associated equipment. The desiccator top was covered with a Plexiglas plate similar to the one described above. Nitrogen gas was bubbled continuously through the soil suspension at a low flow rate ( 15 to $25 \mathrm{ml} \mathrm{min}{ }^{-1}$ ) to remove oxygen and to promote hypoxic conditions in the soil suspension. When the Eh set on the meter relay was reached, the air pump was activated to pump air (oxygen) into the soil suspension to maintain the Eh at the set value.

The experiment consisted of 2 levels of soil aeration (+489 and $-40 \mathrm{mV})$ and 4 levels of salinity $(0,5,15$ and $25 \mathrm{ppt}$ ). Soil Eh was maintained at $489 \pm 26 \mathrm{mV}$ for aerated (high Eh) treatment and at $-40 \pm 23 \mathrm{mV}$ for hypoxic (low Eh) treatments. Throughout the $14 \mathrm{~d}$ experiment, deionized water was added twice per week to compensate for transpirational water losses. Salinity was gradually increased over a $7 \mathrm{~d}$ period to 5,15 and 25 ppt by adding salt solutions to each desiccator daily. Salt solutions were prepared using Instant Ocean Synthetic Sea Salt (Aquarium Systems, Inc., Mentor, $\mathrm{OH}, \mathrm{USA}$ ), with major ionic components of $47 \% \mathrm{Cl}, 26 \% \mathrm{Na}, 6 \% \mathrm{SO}_{4}, 3 \% \mathrm{Mg}, 1 \% \mathrm{~K}$ (percentage of dry wt).

Measurements of leaf conductance $\left(g_{w}\right)$, transpiration $(T r)$ and net photosynthesis $\left(P_{\mathrm{n}}\right)$ were conducted on 4 intact, attached leaves ( 1 measurement per leaf) of plants $5 \mathrm{~h}$ after the start of each photoperiod. This produced 4 measurements per treatment per day. An open gas-exchange system was used for photosynthetic measurements. The apparatus included a multicuvette system supplied with temperature- and humidityconditioned air (Pezeshki 1987). The temperature in each water-jacketed cuvette was controlled by a temperature control unit consisting of a water bath with a dual pumping system, and the air was stirred by an internal fan. An infrared gas analyzer (IRGA), ADC Model LCA-2 was used for differential $\mathrm{CO}_{2}$ measurements. Throughout the experiment PPF was measured with LI-COR Quantum Sensors, and leaf and air temperatures were measured with fine-wire copper constantan thermocouples. A multichannel recorder was used to record these variables.

Transpiration and net photosynthesis were calculated per unit leaf area (single surface) as determined with a surface area meter (Model SI701, SKYE Instruments, Inc., Buckingham, PA, USA). Leaf con- 
ductance was calculated from leaf transpiration rates determined from the water vapor mol-fraction difference across the leaf chamber. Net photosynthetic rates were calculated from the flow rate of air and from the $\mathrm{CO}_{2}$ partial pressure differences between incoming and outgoing air through the chamber as outlined by von Caemmerer \& Farquhar (1981). Water use efficiency (WUE) was calculated from the ratio of $\mathrm{CO}_{2}$ assimilated per amount of $\mathrm{H}_{2} \mathrm{O}$ transpired per $\mathrm{kPa}$ vapor pressure deficit, a measure of $\mathrm{CO}_{2}$ fixed per unit of leaf conductance (Rawson \& Woodard 1976).

Leaf chlorophyll content was determined on 8 leaves per treatment using the method described in detail by Hiscox \& Israelstam (1979). The chlorophyll extract was assayed immediately using a Perkin-Elmer, Model Lambda 3 spectrophotometer.

At the conclusion of the study, plants were separated into foliage and roots and the dry weights of each component were determined. Plant heights were measured at the beginning and end of the experiment, and height growth was determined as the difference between these 2 measurements.

The General Linear Models (GLM) procedure of the SAS System (SAS Institute, Inc, Cary, NC, USA) was used to test for significant differences in gasexchange parameters among the treatment means, by using a repeated-measures design which included the day and the hour of measurement (Moser et al. 1990). Other SAS procedures (ANOVA, TTEST), were used as appropriate to test for significant differences in biomass components among various treatmentcombination means.

\section{RESULTS}

\section{Salinity responses}

Gas exchange of Spartina patens was adversely influenced by increases in salinity under aerobic (high Eh) conditions. For example, $g_{w}$ was reduced by 17 , 46 and $36 \%$ in 5, 15 and 25 ppt treatments, respectively, as compared to control plants (high Eh, no salt) (Table 1, Fig. 1). Similarly, $P_{\mathrm{n}}$ was reduced by 7. 17 and $23 \%$ in 5, 15 and 25 ppt treatments, respectively as compared to control plants (Fig. 2). Water use efficiency remained the same in the $5 \mathrm{ppt}$ treatment ( $105 \%$ of control), and increased in the $15 \mathrm{ppt}$ (161\% of control) and $25 \mathrm{ppt}$ treatments ( $118 \%$ of control). Statistical analyses showed that $g_{\mathrm{w}}$ and $P_{\mathrm{n}}$ were reduced significantly in 15 and 25 ppt salinities. S. patens did not show any reduction in leaf chlorophyll content in response to increased salinity. Chlorophyll content averaged $1.25 \mathrm{mg} \mathrm{g}^{-1} \mathrm{FW}$ (fresh wt) in control plants while it was $1.22,1.37$ and $1.27 \mathrm{mg} \mathrm{g}^{-1} \mathrm{FW}$ in 5,15 and 25 ppt treatments, respectively.

Salinity of $25 \mathrm{ppt}$ resulted in a significant reduction in root dry weight, foliage dry weight and height growth (Fig. 3). At 25 ppt salinity (high Eh), root dry weight reduced by $65 \%$ compared to control plants (0 ppt salinity, high Eh). Similar comparisons showed a $77 \%$ reduction in height growth and a $68 \%$ reduction in foliage dry weight.

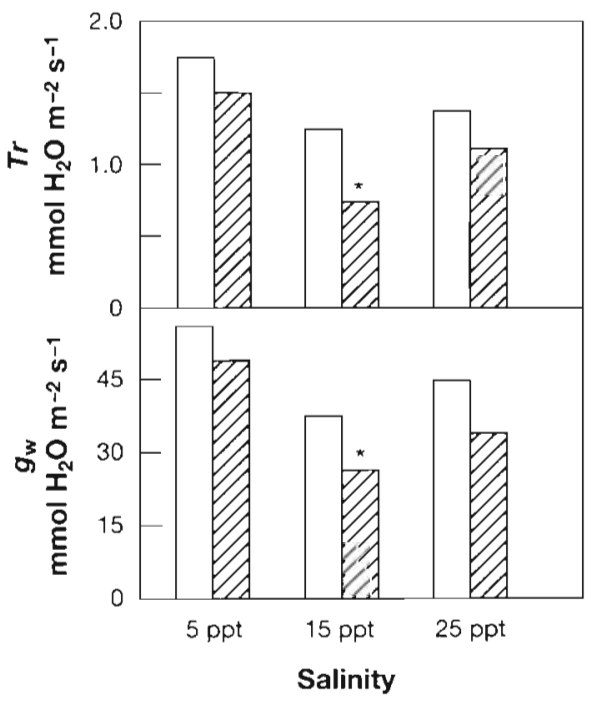

Fig. 1. Spartina patens. Response of leaf conductance $\left(g_{\mathrm{w}}\right)$ and transpiration ( $T r$ ) in marsh grass under high Eh (open bars) and low Eh (hatched bars). "Significant difference ( $p \leq 0.05$ ) between redox potential treatments (high Eh, aerobic vs low Eh, hypoxic) for a given salinity treatment 


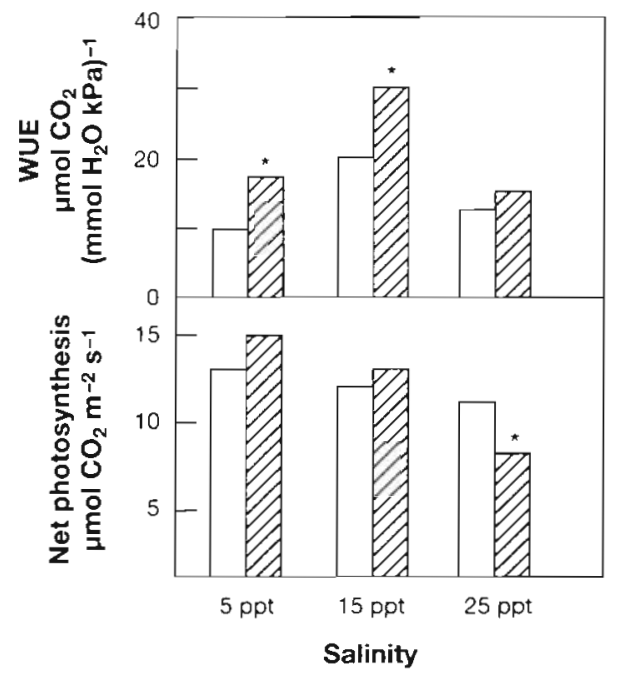

Fig. 2. Spartina patens. Water use efficiency (WUE) and net photosynthesis responses of marsh grass under high Eh (open bars) and low Eh (hatched bars). 'Significant difference $(p \leq 0.05)$ between redox potential treatments (high Eh, aerobic vs low Eh, hypoxic) for a given salinity treatment

\section{Response to salinity and low Eh (hypoxia)}

Leaf conductance was reduced substantially in response to increased salinity combined with low Eh as compared to control plants. $P_{\mathrm{n}}$ and $g_{\mathrm{w}}$ were reduced by as much as 60 and $44 \%$ as compared to control plants, respectively. WUE increased to $238 \%$ in plants subjected to $15 \mathrm{ppt}$ salinity. Comparison of various salinity/Eh combinations are presented in Figs. $1 \& 2$. WUE increased under increasing salinity but was reduced at the highest salinity.

Comparison of plants under the contrasting Eh conditions at each salinity treatment indicated further reduction in $g_{\mathrm{w}}$ (significant for plants in $15 \mathrm{ppt}$ salinity) and $P_{\mathrm{n}}$ (significant for plants in $25 \mathrm{ppt}$ salinity). WUE increased significantly for 5 and 15 ppt plants (low Eh) as compared to 5 and 15 ppt plants (high Eh), respectively. Both hypoxia and salinity influenced gas exchange parameters significantly (Table 2); however. their interaction was not significant.

Combined elevated salinity and hypoxia (low Eh) had adverse effects on growth of Spartina patens

Table 2. Spartina patens. Analysis of variance ( $p$-values) for the effects of hypoxia, salinity and interaction on stomatal conductance $\left(g_{w}\right)$ and net photosynthesis $\left(P_{n}\right)$ of marsh grass

\begin{tabular}{lcc|}
\hline Source & $g_{w}$ & $P_{\mathrm{n}}$ \\
\hline Hypoxia & 0.0482 & 0.0924 \\
SaLinity & 0.0034 & 0.0062 \\
Interaction & 0.2079 & 0.1258 \\
\hline
\end{tabular}

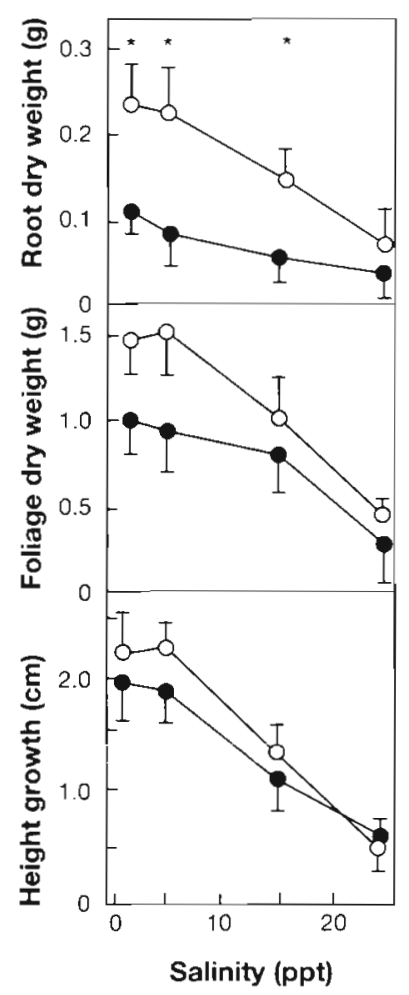

Fig. 3. Spartina patens. Root dry weight, foliage dry weight, and height growth of marsh grass under high Eh (0) and low Eh (-). Each point is the mean for 8 plants. Bars represent $\pm 1 \mathrm{SD}$. "Significant difference $(\mathrm{p} \leq 0.05)$ between redox treatments (high Eh, aerobic vs low Eh, hypoxic) for a given salinity treatment

(Fig. 3). Root dry weights were significantly greater under high Eh and 0,5 and 15 ppt salinity as compared to those salinity treatments combined with low Eh. Under low Eh treatment, root dry weight was not reduced significantly by elevated salinity, indicating that hypoxia had a dominant effect on root development of this species (Fig. 3).

\section{DISCUSSION}

Although salt application reduced photosynthesis in Spartina patens, plants maintained positive net photosynthesis under various salinity treatments in our experiment. The salinity levels tested are within the range currently found in coastal Louisiana primarily due to saltwater intrusion (Salinas et al. 1986). The effects of stomatal closure on net photosynthesis were apparently smaller than the effects on transpiration, resulting in a greater WUE of salt-treated plants. Such responses have been previously reported for other species by Downton et al. (1985) and Flanagan \& Jefferies (1988). This ratio becomes important under saline conditions because of salt transport in the plant 
through the transpiration stream (Flowers et al. 1988). Examination of the gas exchange characteristics of $S$. patens shows low stomatal conductances which restrict $\mathrm{CO}_{2}$ influx and water vapor efflux, and lead to high WUE, averaging $11.4 \mu \mathrm{mol} \mathrm{CO}_{2}$ (mmol $\mathrm{H}_{2} \mathrm{O}$ $\mathrm{kPa})^{-1}$ for control plants. Plants subjected to elevated salinity had WUE substantially increased to as much as $18.3 \mu \mathrm{mol} \mathrm{CO} \mathrm{CO}_{2}\left(\mathrm{mmol} \mathrm{H}_{2} \mathrm{O} \mathrm{kPa}\right)^{-1}$ in $15 \mathrm{ppt}$ which was significantly greater than in control plants $(p<0.05)$. Generally, WUE values were comparable to those found in other halophytes (Flanagan \& Jefferies 1988). The high WUE under increased salinity is necessary for regulation of plant salt balance as found in other halophytes (Andrews \& Muller 1985). In the present study, the interaction between hypoxia and salinity was not significant. We attribute this finding to the Eh conditions (moderate redox condition) and the salt tolerance capability of $S$. patens. The level of hypoxia imposed $(-40 \mathrm{mV})$ was not sufficient to create severe anaerobiosis. Strongly reduced conditions (i.e. Eh lower than $-150 \mathrm{mV}$ ) and higher salinities are likely to change the observed responses.

The net effect of salt stress in plants is reduced growth, which has been attributed to the commonly observed reduction in net photosynthesis (Downton 1977, Longstreth \& Strain 1977, Kemp \& Cunningham 1981, Longstreth et al. 1984, Pearcy \& Ustin 1984). High salinity of the growth medium adversely affects photosynthetic capacity partially by reducing stomatal conductance, resulting in diffusional limitations and depletion of intercellular $\mathrm{CO}_{2}$ concentrations (Downton et al. 1985, Seemann \& Critchley 1985). For instance, Plantago maritima, a halophyte species, showed reduction in net photosynthesis in response to elevated salinities which was attributed to reduced stomatal conductance and the reduction in intercellular $\mathrm{CO}_{2}$ concentrations (Flanagan \& Jefferies 1988). Warren \& Brockelman (1989) showed reduced leaf photosynthesis in response to elevated salinity in Distichlis spicata, a saltmarsh species. Diffusional limitations are usually coupled with metabolic inhibition of photosynthesis (Walker et al. 1983, Ball \& Farquhar 1984, Seemann \& Critchley 1985, Seemann \& Sharkey 1986) due to changes in leaf content of photosynthetic systems and/or alteration in the efficiency in system operations (Pearcy \& Ustin 1984, Seemann \& Critchley 1985, Sharkey 1985, Seemann \& Sharkey 1986). Pearcy \& Ustin (1984) reported significant inhibition of photosynthesis in Spartia foliosa at salinity concentrations of 9 to 26 ppt in coastal California. The observed response was apparently because of both decreases in photosynthetic capacity of mesophyll as well as reduction of stomatal conductance. Indirect evidence also indicates the adverse effect of high salinity on metabolic functions in S. alterniflora (Drake \& Gallagher 1984), a dominant saltmarsh species on the U.S. Gulf Coast. Salinity increase from 15 to $45 \mathrm{ppt}$ reduced growth of S. alterniflora significantly (Linthurst \& Seneca 1981) while salinity of $18 \mathrm{ppt}$ reduced $\mathrm{CO}_{2}$ uptake in S. foliosa. Reduction in leaf chlorophyll content at high salinities has been reported in some mangroves (Ball et al. 1987). In Rhizophora mangle, tissue chlorophyll content increased in response to salinity (Werner \& Stelzer 1990). The effect of salt on reduction of photosynthesis is further confounded by reductions in leaf area, a salinity related response, causing smaller leaves, shorter leaf longevity, and smaller total leaf area per plant (Munns et al. 1982).

Soil hypoxia also influences plant gas exchange functions. Plant responses to flooding include stomatal closure, inhibition of photosynthesis, decrease in water uptake and minerals and changes in hormonal balance (Bradford \& Yang 1981, Bradford \& Hsiao 1982, Kozlowski 1984). In addition to stomatal closure, the photosynthetic capacity of mesophyll decreases due to nonstomatal (metabolic) effects of hypoxia (Bradford 1983). Under laboratory conditions, rapid reduction in soil Eh caused decreased $P_{\mathrm{n}}$ in Spartina alterniflora (Pezeshki et al. 1989) and S. patens (DeLaune et al. 1990).

Other supporting evidence suggests the adverse effects of hypoxia on growth of coastal plants. For example, low soil Eh resulted in significant reduction of root elongation in Spartia patens under laboratory conditions (Pezeshki et al. 1991). Substantial reduction in root growth in $S$. patens has been found when soil Eh fell below $+350 \mathrm{mV}$, the Eh level signifying oxygen disappearance (Pezeshki \& DeLaune 1990). These laboratory findings are supporting previous field data (Linthurst \& Seneca 1981) indicating decreased growth in $S$. alterniflora in response to low soil Eh. The relationship between soil Eh and root elongation in $S$. patens indicated that low soil Eh substantially reduced root elongation despite the existence of an extensive aerenchyma system (Pezeshki et al. 1991). Restricted root growth for this species in response to low soil Eh (Pezeshki et al. 1991) reduces the water uptake capability and may potentially change the source-sink balance for carbohydrate allocation (Drew 1990, Chapin 1991).

\section{CONCLUSIONS}

Gas exchange in Spartina patens was adversely affected by salinity alone and salinity/hypoxia combination. There was no indication of leaf chlorophyll degeneration in response to the treatments. Consequently the observed reduction of photosynthesis is due to other factors including (but not limited to) the substantial stomatal closure. The reduced photo- 
synthesis is in agreement with the significant reductions observed in biomass components as reflected in the final harvest data.

In the present study, a range of salinity representing those found in the U.S. Gulf Coast brackish marshes were tested in conjunction with hypoxia. In coastal brackish marshes, plants must endure salinity and flooding stresses. The brackish marsh vegetation of the U.S. Gulf Coast, with Spartina patens as a dominant species, is deteriorating faster than other wetland habitats (Gagliano \& Van Beek 1970). The increase in salinity accompanied by reducing soil conditions (low Eh), as documented in the present study, cause adverse effects in $S$. patens which in turn reduce productivity of $S$. patens and accelerate wetland deterioration. Results presented may be typical for plants in other coastal regions where vegetation may become subjected to soil hypoxia (low Eh) and elevated salinities due to changes in sea level.

Acknowledgement. Funding for this research was provided by the Louisiana Educational Quality Support Fund, grant no. LEQSF (1991-93)-RDA-07.

\section{LITERATURE CITED}

Adams, R. D., Barrett, B. B., Gane, J. H., McIntire, W. G (1976). Barataria Basin: geologic processes and framework. Louisiana State University, Center for Wetland Resources, Baton Rouge, LA. Sea Grant publication LSU-T-76-006

Andrews, T J., Muller, G. J. (1985). Photosynthetic gas exchange of the mangrove, Rhizophora stylosa in its natural environment. Oecologia 65: 449-445

Ball, M. C., Farquhar, G. D. (1984). Photosynthetic and stomatal responses of two mangrove species to long-term salinity and humidity conditions. Plant Physiol. 74: 1-6

Ball, M. C., Chow, W. S., Anderson, J. M. (1987). Salinityinduced potassium deficiency causes loss of functional photosystem II in leaves of the Grey mangrove, Avicennia marina, through depletion of the atrazine-binding polypeptide. Aust. J. plant Physiol. 14: 351-361

Bradford, K. J., Yang, S. F. (1981). Physiological responses of plants to waterlogging. HortScience 16: 25-30

Bradford, K. J., Hsiao, T. C. (1982). Stomatal behavior and water relations of waterlogged tomato plants. Plant Physiol. 70: 1508-1513

Bradford, K. J. (1983). Involvement of plant growth substances in the alteration of leaf gas exchange of flooded tomato plants. Plant Physiol. 73: 480-483

Chapin, F. S. (1991). Integrated responses of plants to stress. A. centralized system of physiological responses. BioSci. 41 : 29-36

DeLaune, R. D., Pezeshki, S. R., Pardue, J. H. (1990). An oxidation-reduction buffer for evaluating the physiological response of plants to root oxygen stress. Environ. exp. Bot. 30: $243-247$

Downton, W. J. S. (1977). Influence of rootstocks on the accumulation of chloride, sodium and potassium in grapevines. Aust. J. Agric. Res. 28: 879-889

Downton, W. J. S., Grant, W J. R., Robinson, S. P. (1985).
Photosynthetic and stomatal responses of spinach leaves to salt stress. Plant Physiol. 77: 85-88

Drake, B. G., Gallagher, J. L. (1984). Osmotic potential and turgor maintenance in Spartina alterniflora. Oecologia 62: $368-375$

Drew, M. C. (1990). Sensing soil oxygen. Plant Cell Environ. 13: $681-693$

Flanagan, L. B., Jefferies, R. L. (1988). Stomatal limitation of photosynthesis and reduced growth of the halophyte, Plantago maritima L., at high salinity. Plant Cell Environ. 11: $239-245$

Flowers, T. J., Salama, F. M., Yeo, A. R. (1988). Water-use efficiency in rice (Oryza sativa L.) in relation to resistance to salinity. Plant Cell Environ. 11: 453-459

Gagliano, S. M., Van Beek, J. L. (1970). Geologic and geomorphic aspects of deltaiac processes, Mississippi delta system. Hydrologic and Geologic Studies of Coastal Louisiana. Report 1, Coastal Resources Unit, Center for Wetland Resources, Louisiana State University, Baton Rouge

Gleason, M. L., Zieman, J. C. (1981). Influence of tidal inundation on internal oxygen supply of Spartina alterniflora and S. patens. Estuar. coast. Shelf Sci. 13: 47-57

Gosselink, J. G. (1984). The ecology of Delta marshes of coastal Louisiana: a community profile. Fish and Wildlife Service, U.S. Dept Interior. Publ. \#FWS/OBS-84/09

Hiscox, J. D., Israelstam, G. F. (1979). A method for extraction of chlorophyll from leaf tissue without maceration. Can. J. Bot. 57: 1332-1334

Johnson, C. M., Stout, P. R., Broyer, T. C., Carlton, A. B. (1957). Comparative chlorine requirements of different plant species. Plant Soil 8: $337-353$

Kemp, P. R., Cunningham, G. L. (1981). Light, temperature and salinity effects on growth, leaf anatomy and photosynthesis of Distichlis spicata. Am. J. Bot. 68: 162-167

Kozlowski, T T. (1984). Plant responses to flooding. BioSci. 34: 162-167

Linthurst, R. A., Seneca, E. D. (1981). Aeration, nitrogen and salinity as determinants of Spartina alterniflora growth response. Estuaries 4: 53-63

Longstreth, D. J., Bolanos, J. A., Smith, J. E. (1984). Salinity effects on photosynthesis and growth in Alternathera philoxeroides. Plant Physiol. 75: 1044-1047

Longstreth, D. J., Strain, B. R. (1977). Effects of salinity and illumination on photosynthesis of Spartina alterniflora. Oecologia 31: 191-199

Moser, E. B., Saxton, A. M., Pezeshki, S. R. (1990). Repeated measures analysis of variance: application to tree research. Can. J. For. Res. 20: 534-535

Munns, R., Greenway, H., Delane, R., Gibbs, J. (1982). Ion concentration and carbohydrate status of the elongation leat tissue of Hordeum vulgare growing at high external $\mathrm{NaCl}$. II. Cause of the growth reduction. J. exp. Bot. 33: $574-583$

Parrondo, R. I., Gosselink, J. G., Hopkinson, C. S. (1978) Effects of salinity and drainage on the growth of three saltmarsh grasses. Bot. Gaz. 139: 102-107

Pearcy, R. W., Ustin, S. L. (1984). Effects of salinity on growth and photsynthesis of three California tidal marsh species. Oecologia 62: 68-73

Pezeshki, S. R., DeLaune, R. D. (1990). Influence of sediment oxidation-reduction potential on root elongation in Spartina patens. Acta Oecologia 11:377-383

Pezeshki, S. R., Delaune, R. D. (1991). Ecophenic variations in Spartina patens: growth and blomass partitioning. J. Aquat. Plant Mgmt 29: 99-102

Pezeshki, S. R., Matthews, S. W., DeLaune, R. D. (1991). Root 
cortex structure and metabolic responses of Spartina patens to soil redox conditions. Environ. exp. Bot. 31: 91-97

Pezeshki, S. R., DeLaune, R. D., Patrick, W. H. Jr (1989). Effect of fluctuating rhizosphere redox potential on carbon assimilation of Spartina alterniflora. Oecologia 80: 132-135

Pezeshki, S. R. (1991). Population differentation in Spartina patens: gas exchange responses to salinity. Mar. Ecol. Prog. Ser. 72: 125-130

Pezeshki, S. R. (1987). Gas exchange response of tupelogum (Nyssa aquatica) to flooding and salinity. Photosynthetica 21: $489-493$

Pezeshki, S. R., DeLaune, R. D., Patrick, W. H. Jr (1987). Response of Spartina patens to increasing levels of salinity in rapidly subsiding marshes of the Mississippi River Deltaic plain. Estuar. coast. Shelf Sci. 221: 389-399

Rawson, H. M., Woodard, R. G. (1976). Photosynthesis and transpiration in dicotyledonous plants. I. Expanding leaves of tobacco and sunflower. Aust. J. Plant Physiol. 3: 247-256

Reddy, C. N., Jugsujinda, A., Patrick, W. H. Jr (1976). System for growing plants under controlled redox potential-pH conditions. Agron. J. 68: 987-989

Salinas, L. M., DeLaune, R. D., Patrick, W. H. Jr (1986). Changes occurring along a rapidly submerging coastal area. J. coast. Res. 2: 269-284

Seemann, J. R., Critchley, C. (1985). Effects of salt stress on growth, ion concentration, stomatal behavior and photosynthetic capacity of a salt-sensitive species, Phaseolus vulgaris L. Planta 164: 151-162

This article was submitted to the editor
Seemann, J. R., Sharkey, T D. (1986). Salinity and nitrogen effects on photosynthesis, ribulose-1,5-bisphosphate carboxylase and metabolite pool in Phaseolus vulgaris L. Plant Physiol. 82: 555-560

Sharkey, T. D. (1985). Photosynthesis in intact leaves of $C_{3}$ plants: physics, physiology, and rate limitation. Bot. Rev. 51: 53-105

van der Moezel, P. G., Watson, L. E., Bell, D. T (1989). Gas exchange responses of two Eucalyptus species to salinity and waterlogging. Tree Physiol. 5: 251-257

von Caemmerer, S., Farquhar, G. D. (1981). Some relationships between the biochemistry of photosynthesis and the gas exchange of leaves. Planta 153: 376-387

Walker, R. R., Torofalvy, E., Downton, W. J. (1993). Photosynthetic responses of citrus varieties, Rangepur lime and Etrog citron to salt treatments. Aust. J. Plant Physiol. 9: $783-790$

Warren, R. S., Brockelman, P. M. (1989). Photosynthesis, respiration, and salt gland activity of Distichlis spicata in relation to soil salinity. Bot. Gaz. 150: 346-350

Werner, A., Stelzer, R. (1990). Physiological responses of the mangrove Rhizophora mangle grown in the absence and presence of $\mathrm{NaCl}$. Plant Cell Environ. 13: 243-255

Yamasaki, S. (1987). Oxygen demand and supply in $\mathrm{Zi}_{-}$ zania latifolia and Phragmites australis. Aquat. Bot. 29: $205-215$

Yamasaki, T. (1952). Studies of the 'excess moisture injury' of upland crops in overmoist soil from the viewpoint of soil chemistry and plant physiology. Bull. natl Inst. Agric. Sci. (Japan) B1: 1-92

Manuscript first received: October 15, 1992

Revised version accepted: March 29, 1993 